\title{
Relationship between Intermediate EFL Learners' Communication Apprehension, Willingness to Communicate, and Speaking Ability
}

\author{
Maryam Rahmatollahi (Corresponding author) \\ Department of TEFL, College of Literature and Foreign Languages, Islamic Azad University, Karaj Branch, Karaj, Iran \\ Email: mary.rahmatollahi@gmail.com \\ Gholamhassan Famil Khalili \\ Department of TEFL, College of Literature and Foreign Languages, Islamic Azad University, Karaj Branch, Karaj, Iran \\ Email: familkhalili@yahoo.com
}

Received: 09-03- 2015

Published: 01-11- 2015
Accepted: 12-06- 2015

doi:10.7575/aiac.ijalel.v.4n.6p.23
Advance Access Published: August 2015

URL: http://dx.doi.org/10.7575/aiac.ijalel.v.4n.6p.23

\begin{abstract}
Speaking is the first to be acquired in the process of language production. In parallel, the absence of communication apprehension and the presence of willingness to communicate are the essential prerequisites for stringing words together. The purpose of the current study, therefore, was to investigate the underlying patterns of the relationship between communication apprehension (CA), willingness to communicate (WTC), and speaking ability with regard to different contexts and receivers. In so doing, to assign the homogeneity of the sample, Nelson English Language Test was administered and 120 individuals were selected out of 253. Subsequently, Personal Report of Communication Apprehension (PRCA-24) and Willingness to Communicate Questionnaire were employed in order to determine language learners' levels of WTC and CA. Moreover, the researchers utilised the sample interview questions from Task 1 of the intermediate Speaking Test and the speaking scale provided by Farhady, Birjandi, and Ja'farpur (1994) to interview with individuals and determine their speaking ability. Then, the non-parametric data were analyzed using a Spearman's rank order rho correlation. The results illustrated that individuals' speaking ability was neither related to their level of CA nor to their WTC. Moreover, the findings showed that CA and WTC had a negative correlation. Consequently, CA can be considered as one of the predicators of WTC in academic contexts.
\end{abstract}

Keywords: Communication apprehension, speaking ability, willingness to communicate 1. Introduction

Creatures of the same species communicate with one another in various ways. Man is of no exception. Speaking is among the most important features of human race which makes them such unique beings. Within the field of second or foreign language learning, it is believed that foreign language learners should first decide what they want to say. Next, by using appropriate structures and vocabulary, they will be able to express their ideas in a target language.

The process of speaking, however, is much more complex than what it may seem at the first glance. As Mirhassani and Ghaemi (2007) stated, knowing grammatical and semantic rules, by themselves, is inadequate and learners should be aware of patterns of second or foreign language use as well as paralinguistic and nonlinguistic elements. Within the realm of classroom settings, McCroskey and Richmond (2005) considered communication as one of the basic means of learning. However, as Dörnyei (2003) stated, having high levels of second language proficiency and second language communicative competence is not enough; learners should also be willing to communicate in the second language. Thus, teachers, while attempting to help learners, should be aware of the types of contexts in which students experience high and low levels of willingness to communicate (WTC).

Learning English in academic and formal classroom settings of Iran, where it is not common to have the chance to interact with native speakers of English, students have little or no opportunity to practice speaking outside their language classes. Therefore, in such learning contexts where students have limited amount of time, teachers should employ all their power to engage students in discussions and class activities to ensure language production and communication. In brief, they should increase learners' levels of WTC and should provide them with maximum opportunities to initiate and carry on conversations. However, not all students make use of these opportunities.

Students' decision to communicate in the target language depends on their psychological readiness to use that language. In this respect, Brown (2001) asserted that attempting to speak, learners should overcome the anxiety which stems from the risk of saying things that may sound wrong or incomprehensible. According to Woodrow (2006), in-class anxiety and out-of-class anxiety, both, have a negative relationship with individuals' oral performance. More specifically, Frymier (2005) stated that students' communication apprehension (CA) influences their learning outcome and therefore is a crucial academic determinant. 
Although learners' disinclination to speak might be due to many reasons, their levels of CA may also play a crucial role in affecting their desire to keep quiet. Accordingly, exploring possible relationship between learners' CA and their speaking ability and WTC may enable teachers to gain a better understanding of the interaction among the variables and make better predictions about learners' communicative behaviour. It may also offer new techniques and methods for motivating students to talk. In cases students suffer from high levels of anxiety, language teaching tasks and class activities should be adopted in a way that lessen or at least do not increase learners' degrees of apprehension.

To investigate the possible relationship between WTC, CA and speaking ability, a research was designed and conducted. In accordance with the goals of this research, the following research questions were formulated:

$Q_{1}$. Is there any relationship between Iranian intermediate EFL learners' communication apprehension and their speaking ability?

$\mathrm{Q}_{2}$. Is there any relationship between Iranian intermediate EFL learners' willingness to communicate and their speaking ability?

$\mathrm{Q}_{3}$. Is there any relationship between Iranian intermediate EFL learners' communication apprehension and their willingness to communicate?

Subsequently, in line with research objectives, the following null hypotheses were formed:

$\mathrm{HO}_{1}$. There is no relationship between Iranian intermediate EFL learners' communication apprehension and their speaking ability.

$\mathrm{HO}_{2}$. There is no relationship between Iranian intermediate EFL learners' willingness to communicate and their speaking ability.

$\mathrm{H}_{3}$. There is no relationship between Iranian intermediate EFL learners' communication apprehension and their willingness to communicate.

\section{Literature review}

\subsection{Communication apprehension}

Among the various components of foreign language anxiety, CA is said to have a substantial effect in every facets of individuals' academic, occupational and social environment (McCroskey \& Richmond, 2005). CA refers to "an individual's level of fear or anxiety associated with either real or anticipated communication with another person or persons" (McCroskey, 1977, p. 78).

The continuum of communication apprehension ranges from trait-like concepts to situational ones. Arranged on the continuum, there are trait-like, context-based, audience-based and situational CA. First, trait-like CA is believed to be a trait-like personality orientation which is expected to alter little over time. Second, context-based CA is the anxiety experienced by an individual in one type of context. Most people, for instance, have a high degree of apprehension while speaking in a public context. Next, as the term invokes, audience-based CA is concerned with an individual's reactions while communicating with a specific person or group of people. Unlike the first two types, audience-based CA is a situational factor rather than that of a person's personality. Finally, an individual might experience CA when communicating with a given person or group in a distinct situation (Richmond, Wrench, \& McCroskey, 2013).

Specifying the real causes of CA is not an easy task and therefore different scholars and researchers have postulated numerous ideas. McCroskey and Richmond (2005) explained that CA is genetically determined. They asserted that like most personality traits, communication traits in general and trait-like CA in specific are caused by genetically endowed brain systems that create individuals' temperament. Oladipo, Agbajeola, and Adenaike (2012) applied the theory of expectancy learning to the issue. Based on this theory, people develop expectations not only about other people and situations, but also about the probable effects of communication related to those people and those situations. When appropriate expectations are not formed, the person will experience anxiety and when expectations lead to negative outcomes, the person will be frightened. The fear and anxiety that people experience form the foundations of CA.

According to McCroskey and Richmond (2005), communication apprehension could lead to four distinct occurrences including internal discomfort, communication avoidance, communication withdrawal, and overcommunication. As Morreale (2007) uttered, communication apprehensives signal characteristics of nervous feelings, shaky hands and they tend to talk too fast or not talk at all. Dunn and Goodnight (2014) believed that an individual's internal tension might result from his concerns about the way the audience perceive him. Such being the case, controlling excess tension by utilizing some techniques such as taking a deep breath, focusing on the topic, developing a positive attitude, all in all, can help him to present his speech with less apprehension. As Richmond et al. (2013) stated, the treatment of CA depends on the mutual cooperation of the therapist and the patient. Without the patient's commitment, no improvement is likely to be achieved. There exist five frequently used methods for treating CA including systematic desensitization, cognitive restructuring, skill training, visualization, and psychopharmacology. Techniques used in these methods vary from identifying and eliminating illogical thoughts, taking courses related to communication skills, and picturing a successful presentation to taking some drugs. In second language learning contexts, as stated by Woodrow (2006), desensitization and relaxation techniques are beneficial to retrieval interference anxious students. Skill deficient students, on the other hand, would benefit from language learning strategies and scaffolding. 
One of the substantial goals of learning a second or foreign language is that it enables individuals to better communicate and understand people who speak different languages and have different cultural background (Yashima, Zenuk-Nishide, \& Shimizu, 2004). Following MacIntyre, Burns, and Jessome (2011), communication in a second language is a very complex process that embraces a dynamic interplay between the context of learning and the psychology of learners. In this respect, Morreale (2007) stated that individuals should meet three requirements in order to communicate completely. These requirements include motivation, knowledge, and skill. As it can be seen, having positive motivation toward communication is of paramount importance while communicating with others. In addition, as Dörnyei (2005) mentioned, high levels of communicative competence, which is considered as one of the major aims of communicative language teaching approaches, does not necessarily mean that a person tends to engage in any communicative opportunity. In other words, there must be another factor that influences a person's communicative competence and his attempts to put that competence into practice. This factor, which is the result of a combination of a number of psychological, linguistic, and contextual variables, is called willingness to communicate.

MacIntyre, Dörnyei, Clément and Noels (1998, p. 547) defined WTC as a learner's "readiness to enter into discourse at a particular time with a specific person or persons, using a L2". Within English as a Foreign Language (EFL) context, Yashima et al. (2004) stated that WTC serves as a factor that improves communicative skills that individuals require in order to use a language. In the same vein, Dörnyei (2005) considered WTC as the ultimate goal of L2 instruction which is both an end and a means to an end. McCroskey and Richmond (2005) believed that the only direct effect of a person's low WTC is the reduction of his talks. However, indirectly, the consequences of not talking can influence the individual's work environment, social environment and most importantly instructional environment.

Although previous literature considers willingness to communicate as an individual difference variable, influencing the communicative process and outcome of the learning, MacIntyre et al. (1998) tried to broaden the concept to explain the moment-to-moment dynamics of the social situations and the key role of the communicative partner. In cases where individuals have almost the same personality trait, different types of communicative contexts and different types of receivers result in different communicative behaviour. MacIntyre et al. (2011) believed that in a second language context, the verbal and nonverbal behaviour of interlocutors are very important concerning the dynamics of WTC.

MacIntyre et al.'s (1998) 'multi-layered pyramid model' of WTC was a remarkable triumph in changing the concept from a personality trait to a situation specific variable. This model is composed of six categories or layers. Social and individual context, affective-cognitive context, and motivational propensities are the three layers situated at the base of the pyramid and make what is called 'stable enduring influences' which refer to "long term properties of the environment or person that can possibly apply to any situation" (Riasati \& Noordin, 2011, p. 75). Situated antecedent, behavioural intention, and Communication behaviour, on the other hand, form the top three levels of the pyramid and are hypothesized to cause situation-specific influences which can be defined as "more transient and dependent on the specific context in which a person functions at a given time" (Riasati \& Noordin, 2011, p. 75).

Kang (2005) proposed the concept of the 'multilayered situational' WTC construct based on which individuals' situational willingness to communicate depends on the joint role of three interacting psychological antecedents security, excitement and responsibility- that are influenced by situational variables such as topics, interlocutors and conversational contexts. Because the situational variables vary during the act of communication, the resulting situational willingness to communicate is prone to change over time.

\subsection{Speaking ability}

Speaking has been considered as the most conspicuous kind of language ability and proficiency enabling learners to meet their basic needs. Speaking is a challenging process in which, based on the cultural and social context, speakers should decide why, how, and when to communicate (Burns \& Seidlhofer as cited in Martínez-Flor, Usó-Juan, and Soler, 2006).

Speaking has been viewed differently in the last few decades. Up to the end of the 1960s and within the environmentalist approach, speaking was mainly the result of stimulus-response-reinforcement cycles and therefore included repetition, imitation and memorization of the input in isolation. Later, with the emergence of the interactionist approach and cognitive psychology, more emphasis was put on the dynamic and interactive aspects of speaking. Functions produced by spoken language, in addition to social and contextual factors, were considered to be important. Now, due to the influence of cognitive psychology, functional, and pragmatic views of language, speaking is seen as an interactive, social, and contextualized communicative event (Martínez-Flor et al., 2006).

As a part of language learning, it is of the basic needs of any English as a foreign language learner to know how to speak and how to communicate orally. Thus, it is essential for every classroom to spend time on individuals' speaking performance and oral communication. Among different types of classroom speaking performance, the imitative ones are of great significance as these drills offer limited practice by repetition (Brown, 2001). As Harmer (2007) pointed out, repetition enables students to fix new words or phrases in their memory. In addition, it enables them to improve on what they did before and provides them with the opportunity to think about the way they can re-word things.

Speaking ability can be tested either directly or indirectly. In indirect tests, trained examiners evaluate examinees' ability through using a number of elicitation techniques such as asking examinees to describe a picture, make transformation, follow commands, retell a story, explain objects, and so forth. In direct tests, real-life situations are simulated. The best example and the most valid type of direct tests is interview which involves at least two interviewers 
and an interviewee. Interviews usually start with simple questions and move to more difficult ones (Farhady et al., 1994). In addition, individual's oral proficiency can be evaluated by self, peer, and teacher assessments. Providing students with opportunities wherein they can evaluate their own performance is of paramount importance as it enables them to construct and reconstruct their knowledge. Self-assessment helps language learners to bridge the gap between what they already know and their new experience and therefore enhances their understanding (Aeginitou, Nteliou, \& Vlahoyanni, 2010). In a study conducted by Zakian, Moradan, and Naghibi (2012), the researchers claimed that a positive correlation exists between self, peer, and teacher assessments. Consequently, self and peer assessments can be viewed as reliable sources of evaluating one's speaking ability.

\section{Methodology}

\subsection{Participants}

From the pool of 253 participants who took the Nelson English Language Test, 120 intermediate EFL learners of both genders were selected to form a sample which was homogenous in terms of language proficiency. Of these, 80 participants were female $(66.66 \%)$ and 40 were male $(33.33 \%)$. Their age ranged from 11 to 43 and they were all native speakers of Farsi (Persian) learning English as a foreign language in Language institutes.

\subsection{Instruments}

In order to collect the data required for achieving the research objectives, several steps were taken. First, to collect a sample which was homogenous, the Nelson English Language Test was administered. The 50 multiple choice items were designed to test individuals' grammatical control and communicative competence. Second, the researchers used PRCA-24 as the instrument for measuring language learners' level of communication apprehension. As Morreale (2007) stated, Personal Report of Communication Apprehension "is highly reliable $(\alpha>.90)$ and has a very high predictive validity" (p. 8). The instrument consists of 24 statements indicating individuals' feelings about communication with other people. The instrument makes it possible to gain sub-scores on the contexts of public, meeting, group, and interpersonal or dyadic context-based communication apprehension.

Next, willingness to communicate scale, provided by McCroskey (1992), was used in order to determine language learners' tendency toward or away from a communicative encounter. This scale is composed of 20 items, of which 8 items are fillers. The scale enabled the researchers to obtain individuals' total score on WTC classified in terms of three sub-scores on the types of receivers -including a stranger, an acquaintance, and a friend- and four sub-scores on the type of contexts - including public, meeting, group, and dyad.

Finally, as Farhady et al. (1994) stated, among the direct tests of speaking, interviews are the most valid one. Interviews are fairly reliable and rationally practical. Therefore, the researchers used sample interview questions from Task 1 of the intermediate speaking test provided by British Council Hungary. Employing the scale proposed by Farhady et al. (1994), the researchers measured students' speaking abilities.

\subsection{Procedure}

The study was conducted at seven English language institutes in Tehran and Karaj in 2013 and 2014. The data were collected in 42 sessions. In order to provide a homogenous sample, the participants took the Nelson English Language Test (Test $250 \mathrm{~A}$ ). The maximum time allocated for the test was fifty minutes. It was administered as a pencil-and-paper test and students simply answered multiple choice items by picking the correct options. Based on the results of the test scores, 120 learners were selected out of 253. Then, the two questionnaires were administered to determine EFL learners' level of CA and WTC. The participants were asked to answer all questions and they were told that no answer would be considered as right or wrong. In order to test speaking ability, participants were interviewed. The interviews were simultaneously recorded. The records were then rated by two raters in order to obtain reliable and precise results.

\subsection{Design}

The study was conducted through a descriptive method as it aimed to give an accurate account of the phenomenon status quo. Considering the fact that the researchers neither modified any variables nor controlled the flow of events, the design of the study was an ex post facto design in which the variables were not manipulated and randomized and the researchers observed the scene after one variable appeared and the other was consistently associated (Best \& Kahn, 2006).

\section{Results and discussion}

For the purpose of the current study, the Nelson English Language Test was administered to ensure the homogeneity of the sample. Individuals' speaking ability was tested through interviews. Then, Personal Report of Communication Apprehension (PRCA-24) and Willingness to Communicate Questionnaire were given to the students. The data were then submitted to the Statistical Package for Social Science 21 (SPSS). In order to assure that the results of the individuals' speaking ability test display acceptable statistical qualities, reliability estimation was run. As the rating marks were ordinal, to investigate the research questions, the Spearman correlation was employed for the major analyses.

\subsection{Intra-rater and inter-rater reliability}

The Spearman's rank order rho was employed in order to calculate the intra-rater and inter-rater reliability of the participants' speaking ability rated by the raters. 


\begin{tabular}{llll}
\hline & & Speaking2 & speaking3 \\
\hline \multirow{2}{*}{ Speaking 1} & Correlation Coefficient & $.943^{* *}$ & $.937^{* *}$ \\
& Sig. (2-tailed) & .000 & .000 \\
& $\mathrm{~N}$ & 120 & 120 \\
\hline
\end{tabular}

Note. ${ }^{* *} \mathrm{p}<.01$, two-tailed.

Examining the intra-rater reliability of the speaking ratings, the results, as shown in Table 1, indicated that the Spearman rank order correlation is .937 which is considered highly significant at the $<.01$ level for a two-tailed prediction. Thus, it can be claimed that the speaking ratings are significantly reliable. Moreover, as it can be seen, a highly positive correlation coefficient (i.e., .943) can be observed between participants' speaking ratings. The amount of correlation is significant at the $<.01$ level. Hence, inter-rater reliability of the ratings is established.

Having measured the reliability indexes, the researchers investigated the relationship between the research variables including communication apprehension, willingness to communicate, and speaking ability.

4.2 Communication apprehension and speaking ability

The relationship between intermediate EFL learners' total CA and their speaking ability was investigated using the Spearman's rank order rho.

Table 2. Correlation between communication apprehension and speaking ability

\begin{tabular}{lllll}
\hline & & & CA.total & speaking.average \\
\hline \multirow{3}{*}{ Spearman's rho } & & Correlation Coefficient & 1.000 & .004 \\
& CA.total & Sig. (2-tailed) &. & .969 \\
& speaking.average & $\mathrm{N}$ & 120 & 120 \\
\hline
\end{tabular}

Note. $\mathrm{p}=.004$, two-tailed.

As the result of the correlation, presented in Table 2, indicates, a negligible correlation coefficient (i.e., .004) can be observed between the participants' total CA and their speaking ability. This amount of correlation coefficient is negligible since the level of the significance is .969 which is more than the $\mathrm{p}$-value $<.05$.

Table 3 aims to provide readers with more details on the relationships between the subjects' scores on CA, subcategories of CA, and their speaking ability.

Table 3. Correlations between participants' total communication apprehension, sub-categories of communication apprehension, and speaking ability

\begin{tabular}{|c|c|c|c|c|c|c|c|c|}
\hline & & & Epecking averazอ & Ca xotal & CAintercersonel & Cin.zrous & CA.megtinc & CApbic \\
\hline \multirow{18}{*}{ Spesman's ro } & \multirow{3}{*}{ sreaking arerage } & Correlator Coeficient & 1.600 &. $\mathrm{CO} 4$ & .037 & .061 & $.180^{\circ}$ & .028 \\
\hline & & lig [Feriled! & & 569 & 8月9 & $50 \pi$ & 043 & 758 \\
\hline & & N & 120 & 120 & 120 & 120 & 123 & 20 \\
\hline & \multirow{3}{*}{ Catetel } & Correlation Coefiziert & .001 & 1.000 & $.61 \varepsilon^{-}$ & $7 \bar{j} 11$ & $.538^{\prime \prime}$ & $\varepsilon 05^{-\prime}$ \\
\hline & & Sig. [ataledi & .569 & . & ס20 & .000 & בנס & .000 \\
\hline & & k & 120 & 120 & 120 & 120 & 123 & 20 \\
\hline & \multirow{3}{*}{ CA.intarfersoาa } & Conzlaton Coefiviert & .007 & $.619^{-}$ & 1.000 & 35 & $330 "$ & $279^{-1}$ \\
\hline & & Sig. (c-aladi) & .680 & .200 & . & .000 & 003 & .002 \\
\hline & & N & 120 & 120 & 120 & 120 & 12J & 20 \\
\hline & \multirow{3}{*}{ CA.group } & Cursular Cueficient & $-\infty E_{1}$ & $.751^{-}$ & $36 \mathrm{~s}^{\circ}$ & 2.000 & $198^{\circ}$ & $540^{\circ}$ \\
\hline & & Sig $\{2$ trilad $\}$ & .507 & .000 & .000 & & 0,43 & .000 \\
\hline & & $\mathrm{N}$ & 120 & 120 & 120 & 120 & 120 & $12 \mathrm{D}$ \\
\hline & \multirow{3}{*}{ CArreeting } & Correlx on Coefficient & $.80^{\prime \prime}$ & $699^{\circ}$ & $330^{\circ}$ & $.185^{\circ}$ & 1000 & $218^{\circ}$ \\
\hline & & Sig (2-tziled) & .049 & .000 & .000 & .040 & . & .017 \\
\hline & & $\mathrm{N}$ & 120 & 120 & 120 & 120 & 120 & 120 \\
\hline & \multirow{3}{*}{ CA putic } & Carrelaton Coeffisient & .028 & $.8 c 5^{\circ}$ & $279^{\prime \prime}$ & $540^{\circ \prime}$ & $218^{\circ}$ & 1.000 \\
\hline & & Sig (2triled) & 759 & 000 & 0.22 & .000 & 017 & \\
\hline & & $\mathrm{N}$ & 120 & 120 & 120 & 120 & 120 & 120 \\
\hline
\end{tabular}

The results indicate that while all the CA subcategories are significantly interrelated, there is only a slight positive correlation (i.e., .180) between learners' CA within a meeting context and their speaking ability and this implies the existence of a significant, but weak correlation at the $<.05$ level for a two-tailed prediction. 
4.3 Willingness to communicate and speaking ability

Employing the Spearman's rank order rho, the researchers investigated the hypothesis that the learners' level of WTC is not relevant to their speaking ability. The findings of the study are shown in Table 4.

Table 4. Correlation between willingness to communicate and speaking ability

\begin{tabular}{lllll}
\hline & & & WTC.total & speaking.average \\
\hline \multirow{3}{*}{ Spearman's rho } & WTC.total & Correlation Coefficient & 1.000 & .029 \\
& & Sig. (2-tailed) &. & .751 \\
& speaking.average & $\mathrm{N}$ & 120 & 120 \\
\hline
\end{tabular}

Note. $\mathrm{p}=.751$, two-tailed.

Based on the information presented in Table 4, it is inferred that the learners' total WTC does not seem significantly correlated with their speaking ability. In fact, the Spearman's correlation coefficient is .029 and is negligible.

In Table 5, considering the WTC sub-categories, the researchers intended to offer more details to the linkage between the participants' willingness to communicate and their speaking ability.

Table 5. Correlations between participants' total willingness to communicate, sub-categories of willingness to communicate on the type of contexts and receivers and speaking ability

\begin{tabular}{|c|c|c|c|c|c|c|c|c|c|c|c|}
\hline & & & 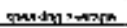 & $A T r, T d V$ & Q-". ratam:-", & 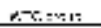 & $\therefore$ arrel-: & $A-C_{0 . z}$ & $\because \pi \mathrm{r}, \mathrm{n}$ & ATr vquimer:", & ATr,d:Av:* \\
\hline & & 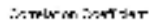 & $::$ & $m$ & $\mathrm{~m}$ & $\pi$ & $n$ & MT & $\therefore 8$ & $: \because$ & 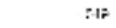 \\
\hline & 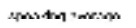 & की $x$ in: & & דed & i & $41 \%$ & $m$ & is. & ווm & $m$ & ? \\
\hline & & 4 & 17 & in & $m$ & $\because$ & $n$ & $m$ & $m$ & 17 & 12: \\
\hline & & 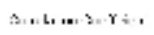 & $y$ & $\cdot m$ & $\cdots$ & $=94^{-}$ & ${ }^{-}$ & "גו" & $\therefore$ & s: & me \\
\hline & Mistil & $\Rightarrow 21 . \mathrm{k}$ & $\therefore$ & & sou & .2 & $m$ & $w$ & $\ldots$ & $\ldots$ & $\mathrm{s}$ \\
\hline & & y & 16. & ניו & נו & 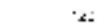 & נים & טיב & $\cdot i z$ & 16. & I: \\
\hline & & 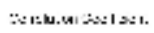 & $\therefore$ & $\approx s$ & ine & ... & . & יווי & $=$ & »" & $\mathrm{Br}$ \\
\hline & 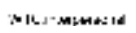 & 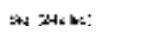 & 44: & $w$ & . & a: & $w^{*}$ & is & H & $:::$ & $::$ \\
\hline & & 4 & I: & עי & נום & $:$ & $\cdot s$ & بـا & $n$ & I: & a \\
\hline & & :ates is : : & $=: 1$ & $n *^{*}$ & $::$ & Ia: & $\mathrm{ve}^{-}$ & $\therefore \kappa$ & $: z^{\prime}$ & No: & $\therefore$ \\
\hline & ST & n > > lan: & 17 & $\mathrm{~mm}$ & $m$ & & $m$ & $\mathrm{mon}$ & $n$ & $:=$ & : \\
\hline & & 4 & 1:: & $1 \times$ & n & $\because:$ & $n$ & 16 & יזי & 1:: & $18:$ \\
\hline & & 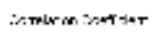 & $\because 1$ & 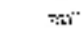 & 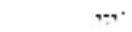 & $\approx ;$ & $1 \mathrm{~m}$ &. $\mathrm{n}^{*}$ & $\because$ & BS: & $\therefore{ }^{\circ}$ \\
\hline \multirow[t]{14}{*}{ soume. } & Nllinst. & su & $=\varepsilon:$ & $w$ & $m$ & 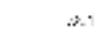 & . & $w$ & $m$ & ... & $s$ \\
\hline & & y & 16. & נכיו & נn & 2 & " w & עבו & 2 & 16. & $1:-2$ \\
\hline & & 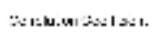 & $-1:$ & $\therefore$ & $\therefore$ & $H E^{\circ}$ & tes" & $\cdot: k$ & $\therefore$ & $w 011^{-}$ & 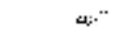 \\
\hline & $x / 6=d=$ & 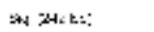 & :ะ4 & wo & $\therefore$ & : $:$ & $\mathrm{sk}$ & & $m$ & $:::$ & : \\
\hline & & 4 & i: & |نli & נה" & : & $\cdot s$ & ل1. & 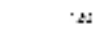 & i:: & i: \\
\hline & & 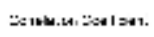 & $=$ & 20 & $:=:^{-}$ & $:=$ & $A 2 i^{\prime}$ & $s$ & 1.02 & $\Leftrightarrow$ & : $:$ \\
\hline & $S I C+N=$ & :n 州象: & $m$ & 144! & $m+1$ & $a::$ & 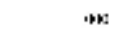 & 144. & & $:=$ & :1s \\
\hline & & व & $1:=$ & 17 & $m$ & $\because$ & $m$ & 16 & יר & : & $1::$ \\
\hline & & 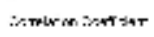 & $:-$ & $m$ & $\because$ & 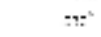 & $m^{-}$ & ici" & $=12^{\prime}$ & $::$ & $\therefore$ \\
\hline & $:$ str. velvirer: & 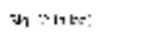 & $m$ & $m$ & $m$ & $m$ & $m$ & $\mathrm{mos}$ & $m$ & & $m$ \\
\hline & & 4 & 17 & in & $n$ & $\%$ & $n$ & $1 \mathrm{~m}$ & $\Leftrightarrow$ & 17 & $1 \%:$ \\
\hline & & 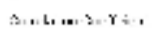 & -4 & $m$ & $\because$ & $\mathrm{NH}^{-}$ & $1 \times 1^{-}$ & "דis & $\Leftrightarrow$ & $\sin$ & i: \\
\hline & 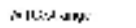 & औ & $\therefore:$ & $w$ & $m$, & ... & $m e x$ & $w$ & $\therefore$ : & $\ldots$ & \\
\hline & & y & 16. & ניטו & נر & $\cdot 2$. & ה & עבו & : & 1 .. & $1 \therefore$ \\
\hline
\end{tabular}

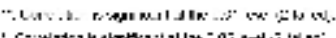

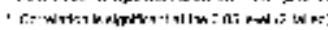

As it is observed, except for the relationship between WTC in interpersonal and public contexts, other contextual subcategories of WTC are weakly interrelated. Meanwhile, there is no considerable relationship between these subcategories and the participants' speaking ability. The Spearman's rho correlation test statistics for the participants' speaking ability and CA within public, meeting, group and interpersonal contexts are -.017, $-.021, .071$, and .070 respectively which are all more than the chosen significance level ( $\mathrm{p}$-value $<.05)$.

Moreover, the results indicate that the subcategories of WTC for different type of receivers are interrelated. However, there is no relationship between the participants' tendency to initiate a conversation (reflected as their WTC) with respect to the type of receiver and their speaking ability at the p-value $<.05$. As it can be observed, the Spearman's rho correlation coefficients for the individuals' speaking ability and their WTC with a stranger, an acquaintance, and a friend are $-.049, .038$, and .019 respectively which are all negligible.

\subsection{Communication apprehension and willingness to communicate}

The next investigated factor in the study is the possible relationship between the individuals' level of CA and their level of WTC.

Table 6. Correlation between participants' total level of communication apprehension and their willingness to communicate

\begin{tabular}{lllll}
\hline & & & CA.total & WTC.total \\
\hline \multirow{3}{*}{ Spearman's rho } & & Correlation Coefficient & 1.000 & $-.189^{*}$ \\
& CA.total & Sig. (2-tailed) &. & .039 \\
& WTC.total & $\mathrm{N}$ & 120 & 120
\end{tabular}

Note. ${ }^{*} \mathrm{p}<0.05$ level, two-tailed. 
Based on the outcome of the statistical analysis presented in Table 6 , the researchers claim that individuals' CA does significantly, but negatively correlate with their WTC as the correlation coefficient is -.189 which is significant, but low at the chosen significance level $(\mathrm{p}$-value $<.05)$ for a two-tailed prediction.

Table 7 presents more details about the underlying patterns of the relationship between the variables.

Table 7. Correlations between participants' level of communication apprehension and their level of willingness to communicate

\begin{tabular}{|c|c|c|c|c|c|c|c|c|c|c|c|}
\hline & & & 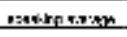 & חו: & nTCITr'me-4 & 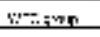 & atcrerth & striatre & $\mathrm{ntc}+\mathrm{m}$ & 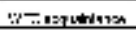 & atcobripr \\
\hline & & 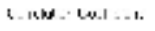 & ws & ses & $n \cdot v$ & N.1 & $\therefore$ & o1. & ניעי & 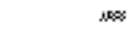 & w: \\
\hline & 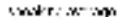 & $\mathrm{A}: \hat{\mathrm{a}} \mathrm{t} \mathrm{x}-1 \mathrm{1}$ & & ה.) & at & $\therefore$ & $\therefore$ & $\because s$ & $m$ & ידי & $\omega$ \\
\hline & & r. & $1 \pi$ & $m$ & w & $1 x$ & $\because$ & 16 & n & $m$ & $13 x$ \\
\hline & & 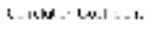 & k: & 1000 & \$ & $\exists i$ & $\therefore$ &.$n \infty$ & $\therefore 2^{\circ}$ & $\because i^{\circ}$ & $m$ \\
\hline & 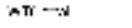 & $A: \hat{a}+1-1$ & $\because 1$ & & mo & $m$ & $\approx *$ & $\mathrm{mos}$ & in & $m$ & in \\
\hline & & เ. & $10:$ & $m$ & $1 w$ & $x$ & $\because$ & 16 & $\eta$ & $m$ & $13 x$ \\
\hline & & 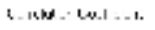 & $w: 5$ & $\rightarrow \infty$ & $\cos x$ & an & $x$ & ניו: & $\because \%^{\circ}-1-10$ & $\ldots *^{\circ}-1-9$ & $\mathrm{Na}$ \\
\hline & $A \pi k \cdot w$ & $A: \hat{A}|\vec{\gamma}-1|$ & $\cdot 4$ & $m$ & & inn & $\cdots$ & ines & in & $m$ & we \\
\hline & & เ. & $17:$ & $m$ & 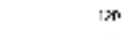 & 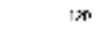 & $\because$ & $i x$ & $\eta$ & $m$ & $13 x$ \\
\hline & & 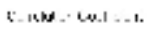 & 6.1 & 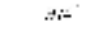 & $A M$ & wen & $: 4$ & رتـ & $\because y^{\circ}$ & $\cdots$ & $x$ \\
\hline & $A \pi, \boldsymbol{N}: \mathrm{s}:$ & $\mathrm{A}: \hat{\mathrm{a}} \mathrm{t}-1 \mathrm{1}$ & $\therefore$ & $m$ & $m$ & & $\because$ & $\mathrm{mos}$ & in & $m$ & is \\
\hline & & r. & $10:$ & $m$ & $1 w$ & $1 x$ & $\because$ & $m$ & ท & $m$ & 13 \\
\hline & & 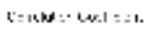 & $k 1$ & $i s$ & $A B$ & هيs & $1 . \cdots$ & $-\infty$ & $=2 i^{\circ}$ & $\because$ & - \\
\hline \multirow[t]{14}{*}{$=\ldots \ldots+\cdots$} & נטי....... & $x: \cdots$ & $\omega x$ & $m$ & $\ln$ & $n$ & & 14a" & 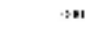 & יו" ln & 14. \\
\hline & & I. & $1 \%:$ & $n$ & $x$ & $i x$ & $\because$ & $x$ & $n$ & $n$ & $1 x$ \\
\hline & & $c=1+\infty=-\cos =01$. & $.21:$ & $i=1$ & . & $\leftrightarrow$ & $4: 2$ & sk & $::^{\circ}$ & $=$ & $\rightarrow r$ \\
\hline & All pedter & $x: \cdots$ & nat & $m$ & 16. & $m$ & & & $n$ & יו & 14. \\
\hline & & t. & 1:? & $n$ & $x$ & $i x$ & $\because$ & $x$ & $n$ & $n$ & $1 x$ \\
\hline & & 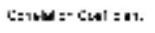 & w12 & .20 & $:=11$ & sth & $2:=$ &.$m$ & $1.2 \mathrm{~N}$ & $24 i^{\circ}$ & I:2 \\
\hline & A11 . I & $x: \because 1$. & sen & m & $m$ & $m$ & & 19es & & $m$ & $m$ \\
\hline & & I. & 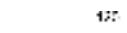 & $n$ & $x$ & 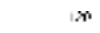 & $\pi$ & $n$ & $n$ & $n$ & $1 x$ \\
\hline & & 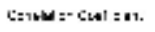 & ve: & $A 3:$ & : & נגו & $2 x$ & $x ; 1$ & $=4 i^{\circ}$ & (1950 & كاع. \\
\hline & All...... & $x: \because 14$ & $n$ & $m$ & 11 & $m$ & & ses & $m$ & & 148 \\
\hline & & t. & $1: 8$ & $n$ & $x$ & $w$ & $\because$ & 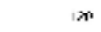 & v & $n$ & $1 x$ \\
\hline & & 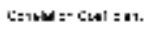 & .145 & (:s' & $.2 \pm \sigma^{\prime}$ &. & $4: 4$ & $\rightarrow r$ & $10^{\circ}$ & a: & $m$ \\
\hline & $A \| \cdots$. & $x: \cdots$ & 14 & $m$ & 114. & $m$ & & 194: & $\because$ & $m$ & \\
\hline & & t. & 1:?: & $n$ & $n$ & $n$ & $\because$ & $x$ & 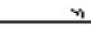 & $n$ & $1 x$ \\
\hline
\end{tabular}

C.

Presenting more details about the underlying patterns of the relationship between the variables, Table 7 indicates that the individuals' sub-scores of CA on the type of contexts correlate negatively with their total level of WTC. However, in almost all contexts the amounts of correlations are negligible. As it can be observed, it is only the subjects' CA within a meeting context that correlates significantly with their total WTC. In this respect, the observed rho of -.190 indicates that there is a weakly significant, but negative correlation between these two variables at the $<.05$ level.

In addition, quick look at Table 7 reveals that a negative relationship exists between learners' willingness to communicate in a meeting context and their total score of CA. The Spearman's rank order rho is -.276. The actual pvalue is .002 which is less than the .01 level of significance. Based on these results, it can be inferred that the relationship between these two variables, though low in strength, is significant. All of the subcategories of WTC negatively correlate with CA.

Next is the relationship between the participants' general CA and their scores on the sub-categories of WTC classified according to the type of receivers. As it can be seen, a negative and modest correlation coefficient exists between the participants' tendency to initiate communication with strangers and their total CA. The correlation coefficient is -.331 and is significant at the $\mathrm{p}$-value $<.05$.

Finally, concerning the relationship between the participants' sub-scores of CA and WTC with regard to different type of contexts, it is observed that the subjects' CA in a meeting context has a significant negative correlation with that of their WTC. The correlation coefficient obtained from these two variables is -.268 which is considered low since the actual pvalue is .003 at the .01 level.

\section{Conclusion}

There are definitely many factors influencing individuals' behaviour within an act of communication. How well we are able to communicate, how willing we are, and how much anxiety we experience in a communicative encounter have profound effects on our everyday interaction. The situation is even more complicated when individuals attempt to express themselves via a language other than their mother tongue as they may suffer from inadequate linguistic, paralinguistic, and non-linguistic repertoires.

Unquestionably, individuals' psychological tendency and their ability to utilize a foreign language have a deep impact on their oral communication. Therefore, the current study focuses on the relationship between Iranian intermediate EFL learners' communication apprehension, willingness to communicate, and speaking ability.

In the process of foreign language learning, CA plays a significant role. In addition, speaking is believed to be at the center of anxiety provoking tasks (Horwitz, Horwitz, \& Cope, 1986). Finding any relationship, therefore, is of great importance. In the study, the researchers found that, except for the level of CA within a meeting context, there exists no considerable relationship between CA, sub-categories of CA, and speaking ability. As it was observed, no significant correlation is perceived between individuals' CA and their speaking ability. Thus, the researchers conclude that if it is said that speaking is among the anxiety provoking activities in foreign language classes, it is not the communication apprehension factor that makes it a painful process, but probably that of test anxiety, fear of negative evaluation, etc. 
Moreover, factors such as individuals' ability to control their emotions, excitement, and feelings may have influenced the results. In other words, the participants' self-control might have neutralized the debilitative effects of CA which influence their language production.

In addition, the tabulated data indicated that while all the CA subcategories are significantly interrelated, individuals' CA in a meeting context correlates significantly and positively with their speaking ability. Meetings are usually considered as anxiety provoking contexts wherein individuals encounter rigid behavioural rules and restrictions (Oladipo et al, 2012). Such being the case, it can be assumed that the formality of the situation probably made participants pay more attention to their language production and their level of proficiency could probably assist them to successfully focus on forms and meanings they were communicating. Thus, it might be right to consider communication apprehension as a facilitative element in some situations. As Bjerregaard and Compton (2011) explained, CA can be beneficial in some situations in a way that it motivates people to work harder and to improve their performance.

The study also investigated the relationship between WTC and speaking ability. As the result suggested the participants' total level of WTC is not relevant to their speaking ability. Whether individuals initiate a conversation with a specific person at a particular point in time and in a certain context is probably a spur-of-the-moment decision that individuals make based on all factors available in a communicative encounter. In fact, probably the decision to initiate a conversation is much more influenced by individuals' situational WTC rather than their general WTC. Accordingly it can be said that individuals' general tendency toward or away from a communicative encounter does not influence their oral proficiency. However, it might be their moment-to-moment decision to initiate an interaction that leads to the development of their language production. In other words, what might be more important in academic and formal classroom settings is individuals' situational willingness to communicate which, as Kang (2005) asserted, is simultaneously influenced by factors such as sense of security, excitement, responsibility, etc. Nonetheless, individuals' general Unwillingness to communicate does affect their situational willingness to communicate.

It should also be noted that although WTC and speaking ability were not directly related to each other, higher levels of WTC could eventually lead individuals to have better oral proficiency. Within an academic environment, WTC influences the frequency of L2 use (Hashimoto, 2002). The more students engage in class discussions, the more chance they have to receive teachers' feedback. As Baghaei and Dourakhshan (2012) stated, such a factor gives the impression that the frequency of the L2 use is possibly the source of higher proficiency.

Furthermore, the results indicated that the subcategories of WTC for different types of receivers are interrelated. However, there is no relationship between the participants' tendency to initiate a conversation (reflected as their WTC) with respect to the type of receiver and their speaking ability. It could be said that it is not individuals' actual speaking ability that determines their desire to talk to different types of receivers, but probably that of their motivation, selfconfidence and self-perceived communication competence. In fact, the way people believe in their capabilities and the self-perception of their own competence may associate with their willingness to communicate.

Another factor which was investigated in the study was the relationship between CA and WTC. Amogne and Yigzaw (2013) believed that individuals' self-perceived oral communication competence and communication apprehension correlate negatively. As Vevea, Pearson, Child, and Semlak (2010) stated, students who are more willing to communicate have lower levels of CA. Coming back to the findings of the current study a negative correlation coefficient is observed between participants' CA and WTC. This suggests that as students were more willing to communicate, they had lower levels of CA. On the one hand, individuals' WTC provokes them to approach a communicative encounter and on the other hand, their CA provokes them to avoid it. Such being the case, it could be true to consider CA as one of the predicators of WTC in language classes as the majority of the highly apprehensive students were less motivated to initiate a conversation.

A more precise look at such a relationship reveals the fact that all of the subcategories of WTC negatively correlate with their total communication apprehension. In addition, CA within a meeting context should be considered as the main predicator of individuals' willingness to approach communicative interactions. Likewise, their WTC in a meeting is the best predicator of their total CA. According to Soureshjani (2012), speaking in meetings is correlated with the anxious feeling that people experience within real or anticipated communication with others in a very small group like a class. Meetings are generally considered as formal situations and as Oladipo et al. (2012) suggested in these situations individuals might suffer from high levels of CA. Their lack of familiarity with the situation may also be influential. Unfamiliarity probably makes learners less confident and more insecure in a way that they prefer to withdraw a communicative encounter (Barjasteh, Vaseghi, \& Neissi, 2012). Consequently, it is highly suggested that such factors should be avoided to the extent possible in academic contexts.

Not surprisingly, speaking to the strangers, students were found to have high CA. As has been said, individuals may feel insecure in an unfamiliar situation (i.e., talking to a stranger in this case) and want to save their face by avoiding communication and not talking. As Kang (2005) explains security is determined by the familiarity among the interlocutors and insecurity reduces individuals' WTC and is indicated by not talking. Considering this issue in an academic environment, teachers should not enforce all learners to take part in class discussions in the first sessions; actually, it might be better if the first sessions are administered in a form of teacher-centered classes and after a period of time a shift shall be made to student-centered classes.

Although in the last decades research on individuals' communicative behaviour has been at the center of scholars' attention (e.g. Kang, 2005; McCroskey \& Richmond, 2005, etc.), there is still more to be done to better understand the 
nature of the concept within the context of a second or foreign language learning. For example, Weavers' (2005) Rasch Model makes it possible for researchers to measure language learners' WTC with respect to both speaking and writing tasks. Another factor which might be effective is the physical presence of the receivers or the channels of communication such as using the internet, sending text messages, etc. As a result, future research shall examine the effect of multi-modality on EFL learners' L2 willingness to communicate or their communication apprehension. Further research can also explore whether teaching styles have any effect on students' communicative behaviour. On this account, factors like collaborative dialogue, vicarious or enactive learning, and metalinguistic corrective feedback can be investigated.

\section{References}

Aeginitou, V., Nteliou, E., \& Vlahoyanni, N. (2010). Reflections in the mirror: the contribution of self and peer assessment in the teaching of speaking skills. GALA, Advances in research on language acquisition and teaching: selected papers, 149-163.

Amogne, D., \& Yigzaw, A. (2013). Oral communication apprehension, competence and performance among maritime engineering trainees. Journal of Media and Communication Studies, 5(1), 5-11.

Baghaei, P. D., \& Dourakhshan, A. (2012). The relationship between willingness to communicate and success in learning English as a foreign language. $M J A L, 4(2), 53-67$.

Barjasteh, H., Vaseghi, R., \& Neissi, S. (2012). Iranian EFL learners' willingness to communicate across different context- and receiver-types. International Journal of English Linguistics, 2(1), 47-54.

Best, J. W., \& Kahn, J.V. (2006). Research in education (10th ed.). Boston: Allyn and Bacon.

Bjerregaard, M., \& Compton, E. (2011). Public speaking handbook. Retrieved May 5, 2014, from http://www.snow.edu/communication/ppublic_speaking_handbook.pdf

Brown, H. D. (2001). Teaching by principles: An interactive approach to language pedagogy (2 ${ }^{\text {nd }}$ ed.). White Plains: Pearson Education.

Dörnyei, Z. (2003). Attitudes, orientations, and motivations in language learning: advances in theory, research, and applications. Language Learning, 53(1), 3-32. http://dx.doi.org/10.1111/1467-9922.53222

Dörnyei, Z. (2005). The Psychology of the language learner: individual differences in second language acquisition. Mahwah, New Jersey: Lawrence Erlbaum Associates.

Dunn, D. M., \& Goodnight, J. C. (2014). Communication: Embracing difference (4 ${ }^{\text {th }}$ ed.). USA: Pearson Education.

Farhady, H. Ja'farpur, A. J., \& Birjandi, P. (1994). Testing language skills from theory to practice. Tehran: SAMT.

Frymier, A. B. (2005). Students' classroom communication effectiveness. Communication Quarterly, 53(2), $197-212$.

Harmer, J. (2007). The practice of English language teaching (4 ${ }^{\text {th }}$ ed.). England: Pearson Education.

Hashimoto, Y. (2002). Motivation and willingness to communicate as predictors of reported L2 use: The Japanese ESL context. Second Language Studies, 20(2), 29-70.

Horwitz, E. K., Horwitz, M. B., \& Cope, J. (1986). Foreign Language classroom anxiety. The Modern Language Journal, 70(2), 125-132.

Kang, S. (2005). Dynamic emergence of situational willingness to communicate in a second language. System, 33(2), 277-292.

MacIntyre, P. D., Burns, C., \& Jessome, A. (2011). Ambivalence about communicating in a second language: A qualitative study of French immersion students' willingness to communicate. The Modern Language Journal, 95, 81-96.

MacIntyre, P. D., Dörnyei, Z., Clément, R. \& Noels, K. A. (1998). Conceptualizing willingness to communicate in a L2: A situational model of L2 confidence and affiliation. Modern Language Journal, 82(4), 545-562.

Martínez-Flor, A., Usó-Juan, E., \& Soler, E. A. (2006). Towards acquiring communicative competence through speaking. In: E. Usó-Juan, \& A. Martínez-Flor (Eds.), Current trends in development and teaching language skills (pp. 137-157). Berlin: Mouton de Gruyter.

McCroskey, J. C. (1977). Oral communication apprehension: A summary of recent theory and research. Human Communication Research, 4(1), 78-96.

McCroskey, J. C. (1992). Reliability and validity of the willingness to communicate. Communication Quarterly, 40(1), 16-25.

McCroskey, J. C., \& Richmond, V. (2005). An introduction to communication in the classroom: The role of communication in teaching and training. Old Tappan: Pearson Education.

Mirhassani, A., \& Ghaemi, F. (2007). Language teaching theories, approaches, methods, and skills. Tehran: Kasa Kavosh.

Morreale, S. (2007). Assessing motivation to communication: Willingness to communicate and personal report of communication apprehension ( $2^{\text {nd }}$ ed.). Washington D.C.: National Communication Association. 
Oladipo, S. E., Agbajeola, R. O., \& Adenaike, F. A. (2012). Assessing communication apprehension among in-service teachers in a university of education. Research on Humanities and Social Sciences, 2(7), 27-31.

Riasati, M. J., \& Noordin, N. (2011). Antecedents of willingness to communicate: A review of literature. Studies in Literature and Language, 3(2), 74-80.

Richmond, V. P., Wrench, J. s., \& McCroskey, J. C. (2013). Communication, avoidance, and effectiveness (6 $6^{\text {th }}$ ed.). Upper Saddle River, NJ: Pearson Education.

Soureshjani, K. H. (2012). The interplay of proficiency level and communication apprehension among EFL learners with a look at their preferences of communicative tasks. International Journal of Instructional Technology and Distance Learning, 9(4), 49-57.

Vevea, N. N., Pearson, J., Child, J. T., \& Semlak, J. L. (2010). The only thing to fear is ... public speaking?: Exploring predicators of communication in the public. JCSTAND, 22, 1-8.

Woodrow, L. (2006). Anxiety and speaking English as a second language. RELC Journal, 37(3), 308-328.

Weaver, C. (2005). Using a rash model to develop a measure of second language learners' willingness to communicate within a language classroom. Journal of Applied Measurement, 6(4), 396-415.

Yashima, T., Zenk-Nishide, L., \& Shimizu, K. (2004). The influence of attitudes and affect on willingness to communicate and second language communication. Language Learning, 54(1), 119-152.

Zakian, M., Moradan, A., \& Naghibi, S. E. (2012). The relationship between self-, peer-, and teacher assessments of EFL learners' speaking. World J Arts, Languages, and Social Sciences, 1(1), 1-5. 